\title{
For a Structured Meaning Account of Questions and Answers
}

\author{
Manfred Krifka
}

\section{Introduction}

In the logical, philosophical and linguistic literature, a number of theoretical frameworks have been proposed for the meaning of questions (see Ginzburg 1995, Groenendijk \& Stokhof 1997 for recent overviews). I will concentrate on two general approaches that have figured prominently in linguistic semantics, which I will call the proposition set approach and the structured meaning approach (sometimes called the "propositional" and the "categorial" or "functional" approach). I will show that the proposition set approach runs into three problems: It does not always predict the right focus structure in answers, it is unable to distinguish between polarity (yes/no) and a certain type of alternative questions, and it does not allow the formulation of an important condition for a type of multiple constituent questions. On the other hand, I will show that the main argument brought forward against the structured meaning framework, namely that it does not give us an elegant way to account for embedded questions, does not withstand closer scrutiny. In this I will take up an issue raised in von Stechow (1990), namely, that the greater expressive power of the structured meaning approach might be necessary for the proper treatment of semantic phenomena like question formation and focusation.

\subsection{Congruent Answers}

Both the proposition set approach and the structured meaning approach relate the meaning of questions to the meaning of congruent answers to those questions (a term coined by von Stechow 1990). That is, the meaning of a question like (1a) is traced back to the meaning of answers like (1b).

(1) a. What did Mary read?

b. Mary read Die Kinder der Finsternis / a novel by Wolf von Niebelschütz.

c. Mary read, and enjoyed, a novel by Wolf von Niebelschütz. 
d. Mary read, or perhaps just bought, Die Kinder der Finsternis.

e. Mary's boyfriend read Die Kinder der Finsternis.

f. I don't know.

g. I won't tell you.

h. Nice weather today.

To be sure, $(1 \mathrm{c}-\mathrm{e})$ are fully acceptable reactions, but they are not congruent to the question. (1c) is an over-informative answer, (1d) is an under-informative answer, and (1e), which is natural under a contrastive topic accent of Mary's boyfriend, is underinformative as well. $(1 \mathrm{f}, \mathrm{g})$ are not answers but acceptable replies, and $(1 \mathrm{~h})$ is a reaction that is either completely off the mark, or will induce certain conversational implicatures.

The notion of a congruent answer can be characterized for simple constituent questions: It is an answer that fills in a constituent for the $w h$-word in the question, and does nothing more than that. In other cases, this notion cannot be defined as easily. It is a theory-dependent notion, and its validity will have to be judged with respect to the success of the theories that work with it.

\subsection{The Structured Meaning Approach}

The structured meaning approach goes back to Ajdukiewicz (1928), as noticed in Hiz (1978). It has been developed by Hull (1975), Tichy (1978), Hausser \& Zaefferer (1979), von Stechow \& Zimmermann (1984), von Stechow (1990) and Ginzburg (1992). Generalizing over a number of important differences between the theories that follow this approach, the basic idea is this:

(2) Question meanings are functions that, when applied to the meaning of the answer, yield a proposition.

For example, simple constituent questions are analyzed as illustrated in (3). The meaning of Who read Die Kinder der Finsternis is a function that, when applied to the meaning of the answer, here Mary, gives a proposition, here the meaning of Mary read Die Kinder der Finsternis.

(3) A: Who read Die Kinder der Finsternis? B: Mary.

$\lambda x[\operatorname{READ}(\mathrm{KF})(\mathrm{x})]$ Question applied to answer:

$$
\begin{aligned}
& \mathrm{M} \\
& \lambda \mathrm{x}[\operatorname{READ}(\mathrm{KF})(\mathrm{x})](\mathrm{M}) \\
& =\operatorname{READ}(\mathrm{KF})(\mathrm{M})
\end{aligned}
$$

I assume some standard version of truth-theoretical interpretation. Atomic meanings are rendered by English words in small caps, and I employ variables and lambda terms 
in the usual way. I understand a meaning representation like $\operatorname{READ}(\mathrm{KF})(\mathrm{M})$ as a proposition, the set of possible worlds in which Mary read Die Kinder der Finsternis. A more explicit representation would have $\lambda i[\operatorname{READ}(i)(\operatorname{KF}(\mathrm{i}))(\mathrm{M}(\mathrm{i}))]$, but to keep notation simple I will suppress the reference to possible worlds here.

Polarity questions (yes/no questions) expect answers like yes and no, which should be considered congruent answers. It is plausible to assume that no is a propositional operator that reverses the truth value, or gives the complement of a proposition $(\lambda \mathrm{p}[\neg \mathrm{p}])$, and that yes is a propositional operator that retains the truth value, that is, the identity function for propositions $(\lambda \mathrm{p}[\mathrm{p}])$.

(4) A: Did Mary read Die Kinder der Finsternis? B: No.

$\lambda \mathrm{f}[\mathrm{f}(\operatorname{READ}(\mathrm{KF})(\mathrm{M}))]$

Question applied to answer:

$\lambda \mathrm{p}[\neg \mathrm{p}]$

$\lambda \mathrm{f}[\mathrm{f}(\operatorname{READ}(\mathrm{KF})(\mathrm{M}))](\lambda \mathrm{p}[\neg \mathrm{p}])$

$=\neg \operatorname{READ}(\mathrm{KF})(\mathrm{M})$

Our notation, as it stands, does not incorporate the meaning of the wh-word itself; it does not distinguish between the following questions:

(5) a. Who did Mary see? $\lambda x[\operatorname{SEE}(x)(M)]$

b. What did Mary see? $\lambda x[\operatorname{SEE}(x)(M)]$

What we need is some way to indicate the function domain of the question meanings; in (5a), this is the set of persons, in (5b), the set of things. We could make this explicit in our notation in various ways, as in (6) or as in (7), which gives the function and its domain as a pair.

(6) a. Who did Mary see? $\quad \lambda x \in \operatorname{PERSON}[\operatorname{SEE}(\mathrm{x})(\mathrm{M})]$

b. What did Mary see? $\quad \lambda \mathrm{x} \in \mathrm{THING}[\operatorname{SEE}(\mathrm{x})(\mathrm{M})]$

(7) a. Who did Mary see? $\langle\lambda x[\operatorname{SAW}(\mathrm{x})(\mathrm{M})]$, PERSON $\rangle$

b. What did Mary see? $\quad\langle\lambda \mathrm{x}[\mathrm{SAW}(\mathrm{x})(\mathrm{M})]$, THING $\rangle$

I will follow here the latter notation convention, which will be slightly more convenient. I will call the first part of a question meaning its background, the second part its restriction. Polarity questions then will be represented as follows:

(8) Did Mary read Die Kinder der Finsternis?

$\langle\lambda \mathrm{f}[\mathrm{f}(\operatorname{READ}(\mathrm{KF})(\mathrm{M}))],\{\lambda \mathrm{p}[\neg \mathrm{p}], \lambda \mathrm{p}[\mathrm{p}]\}\rangle$

The answers that we have considered so far are term answers (cf. von Stechow \& Zimmermann 1984). They are to be contrasted to full answers: 
(9) A: Who did Mary see?

B: Mary saw John.

The meaning of a full answer is simply the question meaning applied to the term answer.

\subsection{The Proposition Set Approach}

The proposition set analysis goes back to Hamblin $(1958,1973)$ and has been further developed and refined by Karttunen (1977) and Groenendijk \& Stokhof (1984). The essential idea is that the meaning of a question is the set of its possible full answers, that is, a set of propositions.
(10) A: Who read Die Kinder der Finsternis?

$$
\begin{aligned}
& \{\mathrm{p} \mid \exists \mathrm{x}[\operatorname{PERSON}(\mathrm{x}) \wedge \mathrm{p}=\operatorname{READ}(\mathrm{KF})(\mathrm{x})]\} \\
= & \{\operatorname{READ}(\mathrm{x})(\mathrm{KF}) \mid \operatorname{PERSON}(\mathrm{x})\} \\
= & \{\operatorname{READ}(\mathrm{KF})(\mathrm{J}), \operatorname{READ}(\mathrm{KF})(\mathrm{M}), \ldots\} \\
& \operatorname{READ}(\mathrm{M})(\mathrm{KF})
\end{aligned}
$$$$
=\{\operatorname{READ}(\mathrm{x})(\mathrm{KF}) \mid \operatorname{PERSON}(\mathrm{x})\}
$$$$
=\{\operatorname{READ}(\mathrm{KF})(\mathrm{J}), \operatorname{READ}(\mathrm{KF})(\mathrm{M}), \ldots\}
$$
B: $\quad$ Mary read Die Kinder der Finsternis.

It is important to keep in mind that $\mathrm{p}$, or READ(M)(KF), stands for propositions (sets of possible worlds), and not for their descriptions. There is a variety of the proposition set analysis which assumes that the meaning of a question is the set of descriptions of those propositions in some representation language (cf. Higginbotham \& May 1981), which is a more expressive framework, as it would allow for syntactic operations on these descriptions that could not be defined for sets of propositions. I will generally assume a restrictive denotational framework here, not a representational one. In this I follow the general tenet of truth-conditional semantics that semantic analysis cannot consist in the mere translation of one language into another one (cf. Lewis 1970).

The natural answer type of the proposition set analysis is a full answer. In Who read Die Kinder der Finsternis? - Mary, the answer has to be spelled out first as Mary read Die Kinder der Finsternis before it can be interpreted. Proponents of the proposition set analysis have rarely discussed how this spelling-out of full answers can be achieved. Presumably, it is by some syntactic process that deletes material recoverable from the question, essentially, all the material except the question constituent. This material has to be retrieved; presumably, the deleted material is interpreted anaphorically in some way or other.

(11) A: Who $[\mathrm{read} \text { Die Kinder der Finsternis }]_{1}$ ?
B: Mary $\varnothing_{1}$.

Spelling out: Mary [read Die Kinder der Finsternis $]_{1}$

The proposition set analysis deals with polarity questions as follows: 
(12) A: Did Mary read Die Kinder der Finsternis? $\{\operatorname{READ}(\mathrm{KF})(\mathrm{M}), \neg \operatorname{READ}(\mathrm{KF})(\mathrm{M})\}$

B: Mary didn't read Die Kinder der Finsternis. $\neg$ READ(KF)(M)

As before, the natural answer of a polarity question is a full answer. But now it is especially difficult to see how the term answers yes and no could be dealt with in this system. The reason is that the two propositions in the question meaning cannot be identified as "positive" and "negative", as one proposition is just the complement of the other - recall that all we have is sets of possible worlds, not their descriptions. We will therefore have to treat yes and no as devices that refer to a syntactic object that is constructed when formulating the question. We could analyze yes as an anaphoric element that refers to the proposition embedded in the polarity question, and no as an anaphoric element that refers to its negation:

(13) A: Did Mary read Die Kinder der Finsternis?

LF:

QU [Mary read Die Kinder der Finsternis]

Interpretation: $\quad[\mathrm{QU}]([$ Mary read Die Kinder der Finsternis $])$

$=\lambda \mathrm{p}\{\mathrm{p}, \neg \mathrm{p}\}(\operatorname{READ}(\mathrm{KF})(\mathrm{M}))$

$=\{\operatorname{READ}(\mathrm{KF})(\mathrm{M}), \neg \operatorname{READ}(\mathrm{KF})(\mathrm{M})\}$

B: Yes $_{1}$.

$\left[\mathrm{Yes}_{1}\right]=[$ Antecedens of 1$]=\operatorname{READ}(\mathrm{KF})(\mathrm{M})$

$\mathrm{No}_{1}$.

$\left[\mathrm{No}_{1}\right]=\neg[$ Antecedens of 1$]=\neg \operatorname{READ}(\mathrm{KF})(\mathrm{M})$

There are a number of variations on the general theme of the proposition set analysis of questions. Karttunen (1977) proposed that the meaning of a question should just be the set of its true answers. (In the following representation, ${ }^{\vee} p$ can be read as " $p$ is true in the actual world".)

(14) What did Mary read? $\left\{\mathrm{p} \mid \exists \mathrm{x}\left[{ }^{\vee} \mathrm{p} \wedge \mathrm{x} \in \mathrm{THING} \wedge \mathrm{p}=\operatorname{READ}(\mathrm{x})(\mathrm{M})\right]\right\}$

If Mary read Die Kinder der Finsternis and nothing else: $=\{\operatorname{READ}(\mathrm{KF})(\mathrm{M})\}$

The reason for this move was to obtain a proper analysis of inferences involving embedded questions, such as Mary knows whether it is raining; it is raining $\Rightarrow$ Mary knows that it is raining, to which I will return in section 5. Notice that Karttunen's theory does not provide for an easy solution for term answers either.

Groenendijk \& Stokhof (1984) proposed another variant, according to which the meaning of a question is the set of its exhaustive answers. This is how they would represent our example question, with possible worlds made visible:

(15) What did Mary read? $\lambda \mathrm{j} \lambda \mathrm{i}[\lambda \mathrm{x}[\operatorname{READ}(\mathrm{i})(\mathrm{x})(\mathrm{M})]=\lambda \mathrm{x}[\operatorname{READ}(\mathrm{j})(\mathrm{x})(\mathrm{M})]],=(1)$ 
We get a relation between possible worlds $j$ and $i$ that obtains if the things that Mary read in $i$ are the same as the things that Mary read in $j$. This is not a set of propositions yet, but it comes close enough - it is an equivalence relation, which stands in a one-toone correspondence with a partition on the set of possible worlds:

(16) Partition corresponding to the equivalence relation (1):

$\{\mathrm{p} \mid \exists i[i \in \mathrm{p} \wedge \mathrm{p}=\{\mathrm{j} \mid \mathbb{D}(\mathrm{i})(\mathrm{j})\}]\}$

If only Die Kinder der Finsternis and Das Totenschiff are under discussion, we get the following set of four propositions:

(17) $\{\operatorname{READ}(\mathrm{KF})(\mathrm{M}) \wedge \operatorname{READ}(\mathrm{TS})(\mathrm{M}), \operatorname{READ}(\mathrm{KF})(\mathrm{M}) \wedge \neg \operatorname{READ}(\mathrm{TS})(\mathrm{M})$, $\neg \operatorname{READ}(\mathrm{KF})(\mathrm{M}) \wedge \operatorname{READ}(\mathrm{TS})(\mathrm{M}), \neg \operatorname{READ}(\mathrm{KF})(\mathrm{M}) \wedge \neg \operatorname{READ}(\mathrm{TS})(\mathrm{M})\}$

As equivalence relations contain exactly the same information as their corresponding partitions, the account of Groenendijk \& Stokhof clearly belongs to the proposition set analysis. But interestingly, to derive this propositional interpretation in a compositional way, Groenendijk \& Stokhof have to go through a construction step that involves question meanings of the structured meaning type, called "abstracts". For question (15), we derive from a zero-place abstract (18a) a one-place abstract (b), which then is turned into the question meaning $(\mathrm{c})$ :

(18) a. [READ(i)(x)(M)]

b. $\lambda x[\operatorname{READ}(i)(x)(M)]$

c. $\lambda j \lambda i[\lambda x[\operatorname{READ}(i)(x)(M)]=\lambda x[\operatorname{READ}(j)(x)(M)]]$

In general, we can derive a propositional interpretation from a structured meaning interpretation, but not vice versa - structured meaning interpretations are more expressive. One of the aims of this paper is to show that we indeed need this additional expressiveness.

\section{Problems with Focus in Answers}

It is an old observation (e.g., Paul 1880) that the prosodic contour of the answer relates an answer to the corresponding question. In particular, the focus of the answer, which is marked by a prosodic peak, corresponds to the meaning of the question:

(19) a. A: Who read Die Kinder der Finsternis?

B: $\quad$ Máry read Die Kinder der Finsternis.

B': *Mary read Die Kinder der Fínsternis. 
b. A: What did Mary read?

B: Mary read Die Kinder der Fínsternis.

B': *Máry read Die Kinder der Finsternis.

The focus pattern of the answer has largely been neglected in the development of theories of question meaning. But it can be integrated. The two frameworks for question meanings suggest different treatments of focus.

\subsection{Answer Focus in the Proposition Set Framework}

The proposition set framework for questions fits with the Alternative Semantics analysis of focus, as developed by Rooth (1985) for contrastive focus, for focus-sensitive operators like only, and for focus-sensitive quantification. Rooth (1992) also deals with focus in answers to questions.

In Alternative Semantics, expressions have, in addition to their ordinary meaning, a set of alternative meanings. The alternatives are introduced by expressions in focus (indicated by a syntactic feature, F, that is realized by accent). This is illustrated in the following examples.

expression ordinary meanings alternatives

(20) $[\text { Máry }]_{\mathrm{F}} \quad \mathrm{M}$

$[\text { Máry }]_{\mathrm{F}}$ read Die $\quad \operatorname{READ}(\mathrm{KF})(\mathrm{M})$

Kinder der Finsternis.

(21) [Die Kinder der

Finsternis $]_{\mathrm{F}}$

Mary read [Die

$\mathrm{KF}$

$\operatorname{READ}(\mathrm{KF})(\mathrm{M})$

$$
\begin{aligned}
& \operatorname{ALT}(\mathrm{M}),=\{\mathrm{M}, \mathrm{J} \ldots\} \\
& \{\operatorname{READ}(\mathrm{KF})(\mathrm{x}) \mid \mathrm{x} \in \operatorname{ALT}(\mathrm{M})\} \\
& =\{\operatorname{READ}(\mathrm{KF})(\mathrm{M}), \operatorname{READ}(\mathrm{KF})(\mathrm{J}), \ldots\} \\
& \operatorname{ALT}(\mathrm{KF}) \\
& =\{\mathrm{KF}, \mathrm{TS}, \ldots\} \\
& \{\operatorname{READ}(\mathrm{x})(\mathrm{M}) \mid \mathrm{x} \in \operatorname{ALT}(\mathrm{KF})\} \\
& =\{\operatorname{READ}(\mathrm{KF})(\mathrm{M}), \operatorname{READ}(\mathrm{TS})(\mathrm{M}), \ldots\}
\end{aligned}
$$

For meanings $\alpha, \operatorname{ALT}(\alpha)$ stands for the alternatives of $\alpha$. The alternatives can either be taken broadly (e.g., $\operatorname{ALT}(\alpha)=$ all objects of the same type as $\alpha$; this is the option that Rooth 1992 chooses), or restrictively $(\operatorname{ALT}(\alpha)=$ the set of relevant alternatives in a particular context); they must contain at least two elements. Example (20) shows that the ordinary meaning of Máry $y_{\mathrm{F}}$ read Die Kinder der Finsternis is the proposition that Mary read Die Kinder der Finsternis, and the alternatives are propositions of the type "x read Die Kinder der Finsternis", where x ranges over persons. Both the ordinary meaning and the alternatives can be derived compositionally from their parts; the rule for the alternatives follows in a straightforward way from the rule for the ordinary meanings.

Notice that while the ordinary meanings of (20) and (21) are the same, their alternatives are different, and correspond to the question meanings. In particular, for congruent answers, the alternatives are supersets or subsets of the question meaning, depending on whether we understand $\operatorname{ALT}(\alpha)$ in a broad way or in a narrow way. This 
is illustrated in (22). The answer Máry $y_{\mathrm{F}}$ read Die Kinder der Finsternis is congruent to the question Who read Die Kinder der Finsternis, as the alternatives of the answer are either supersets (i) or subsets (ii) of the question meaning.

(22) A: Who read Die Kinder der Finsternis?

B: $\quad[\text { Máry }]_{F}$ read Die Kinder der Finsternis.

$$
\begin{aligned}
& \quad\{\operatorname{READ}(\mathrm{KF})(\mathrm{x}) \mid \operatorname{PERSON}(\mathrm{x})\}, \\
& =\{\operatorname{READ}(\mathrm{KF})(\mathrm{M}), \operatorname{READ}(\mathrm{KF})(\mathrm{J}), \ldots\},=(1) \\
& \{\operatorname{READ}(\mathrm{KF})(\mathrm{x}) \mid \mathrm{x} \in \operatorname{ALT}(\mathrm{M})\},=(2)
\end{aligned}
$$

The answer is congruent, as we either have (i) or (ii):

(i) (1) $\subseteq$ (2), if $\operatorname{ALT}(M)=$ all objects of the type of $M$, we have (2) $=\{\operatorname{READ}(\mathrm{KF})(\mathrm{M}), \operatorname{READ}(\mathrm{KF})(\mathrm{J}), \operatorname{READ}(\mathrm{KF})(\mathrm{MOON}), \ldots\}$

(ii) (2) $\subseteq(1)$, if $\operatorname{ALT}(M)=$ a contextually restricted set of persons, e.g., $\{\mathrm{M}, \mathrm{J}\}$ we have (2) $=\{\operatorname{READ}(\mathrm{KF})(\mathrm{M}), \operatorname{READ}(\mathrm{KF})(\mathrm{J})\}$

On the other hand, the answer Mary read [Die Kinder der Finsternis $]_{\mathrm{F}}$ is not congruent, as its alternatives are neither a superset nor a subset of the question meaning; they just overlap in one element.

(23) B:

$$
\begin{aligned}
& \text { *Mary read }[\text { Die Kinder } \\
& \text { der Fínsternis }]_{\mathrm{F}}
\end{aligned}
$$

$$
\begin{aligned}
& \{\operatorname{READ}(\mathrm{x})(\mathrm{M}) \mid \mathrm{x} \in \operatorname{ALT}(\mathrm{KF})\} \\
& =\{\operatorname{READ}(\mathrm{KF})(\mathrm{M}), \operatorname{READ}(\mathrm{TS})(\mathrm{M}), \ldots\},=3
\end{aligned}
$$

The answer is not congruent:

(i) (3) $\nsubseteq$ (1)

(ii) (1) $\nsubseteq$ (3)

(but notice that (1) $\cap(3)=\{\operatorname{READ}(\mathrm{KF})(\mathrm{M})\})$

One necessary qualification of the superset-or-subset criterion is that the subset contains more than one element. Otherwise we will have (3) $\subseteq$ (1) or (1) $\subseteq$ (3) even with noncongruent answers, as they overlap in one proposition. We can plausibly require that both the question and the alternatives of the answer contain more than one proposition: A true question must leave at least two possibilities open, and the contrast indicated by a focus would not be a true contrast if the focused expression does not have at least one proper alternative. This suggests another, simpler criterion: the meaning of the question and the alternatives of the answer have more than one element in common (notice that $\#($ (1) $\cap$ (2) $)>1$ but $\#((1) \cap(3))=1)$. For non-congruent answers, the meaning of the question and the alternatives of the answer have only one element in common, the ordinary meaning of the answer. This suggests the following three criteria for congruent question-answer pairs: 
(24) Possible criteria for congruent question-answer pairs $Q-A$ :

a. $[Q] \subseteq[A]_{\mathrm{A}}$, provided that $\#([Q])>1$

b. $[A]_{\mathrm{A}} \subseteq[Q]$, provided that $\#\left([A]_{\mathrm{A}}\right)>1$

c. $\#\left(\left[A \rrbracket_{\mathrm{A}} \cap[Q]\right)>1\right.$

There is a fourth criterion, which may appear to be the most obvious one. We may assume that congruent question-answer pairs identify the meaning of the question and the alternatives of the answer, i.e., $[Q]=[A]_{\mathrm{A}}$. This identification is not asserted, but presupposed; every answer to a question presupposes that it is a congruent answer. Being a presupposition, the identity statement can be accommodated. We would have to assume an additional restriction for question meanings, RESTR, that is subject to accommodation just like ALT.

(25) A: Who read Die Kinder

$$
\{\operatorname{READ}(\mathrm{KF})(\mathrm{x}) \mid \operatorname{PERSON}(\mathrm{x}), \mathrm{x} \in \operatorname{RESTR}\},=\text { (4) }
$$
der Finsternis?

B: $\quad[\text { Máry }]_{\mathrm{F}}$ read Die Kinder $\quad\{\operatorname{READ}(\mathrm{KF})(\mathrm{x}) \mid \mathrm{x} \in \mathrm{ALT}(\mathrm{M})\},=$ (2) der Finsternis.

Accommodation of (4) $=$ (2) leads to $\operatorname{RESTR}=\operatorname{ALT}(\mathrm{M})$.

The problem with this criterion is that this type of accommodation would rule in noncongruent question-answer pairs:

(26) B': *Mary read [Die Kinder der Fínsternis $]_{\mathrm{F}}$.

$\{\operatorname{READ}(\mathrm{x})(\mathrm{M}) \mid \mathrm{x} \in \operatorname{ALT}(\mathrm{KF})\},=$ (3)

Here, accommodation of (1) $=$ (3) is possible, leading to $\operatorname{ALT}(\mathrm{KF})=\{\mathrm{KF}\}, \operatorname{RESTR}=$ $\{\mathrm{M}\}$, as we then have (1) $=(3)=\{\operatorname{READ}(\mathrm{KF})(\mathrm{M})\}$.

In order to rule out (26) we must ensure that (1) and (3) contains more than one element after accommodation. But this is the same criterion as $(24 \mathrm{c})$.

\subsection{Answer Focus in the Structured Meaning Framework}

The structured meaning framework for questions fits with the structured meaning representation of focus (cf. von Stechow 1981, Jacobs 1984, Krifka 1992; for application to question-answer relations, see von Stechow 1990). Focus leads to a partition of the semantic material of an expression into a background part and a focus part, which I render here as a pair $\langle\mathrm{B}, \mathrm{F}\rangle$ : 
(27) a. $[\text { Máry }]_{\mathrm{F}}$ read Die Kinder der Finsternis. $\quad\langle\lambda \mathrm{x}[\operatorname{READ}(\mathrm{KF})(\mathrm{x})], \mathrm{M}\rangle$

b. Mary read $[\text { Die Kinder der Finsternis }]_{\mathrm{F}} . \quad\langle\lambda \mathrm{x}[\operatorname{READ}(\mathrm{x})(\mathrm{M})], \mathrm{KF}\rangle$

Notice that when we apply the background B to the focus $\mathrm{F}$ to form the meaning B(F), we arrive at the regular interpretation. It is obvious how to express the condition for congruent question-answer pairs in this framework: the background of the question and the answer must be the same, and the focus of the answer must be an element of the background of the question:

(28) Criterion for congruent question-answer pair $Q-A$, where $[Q]=\langle\mathrm{B}, \mathrm{R}\rangle$ and $[A]=\left\langle\mathrm{B}^{\prime}, \mathrm{F}\right\rangle$ :

$\mathrm{B}=\mathrm{B}^{\prime}$ and $\mathrm{F} \in \mathrm{R}$.

This predicts that $(29 a-b)$ is a congruent question-answer pair, as the background of the question and the background of the answer are identical, and the focus is an element of the restriction of the question. But $(29 a-c)$ is not congruent, as the backgrounds differ, and $(29 a-d)$ is not congruent either, as the focus is not an element of the restriction.

(29) a. Who did Mary see?

$\langle\lambda x[\operatorname{SEE}(\mathrm{x})(\mathrm{M})]$, PERSON $\rangle$

b. Mary saw [Jóhn $]_{\mathrm{F}}$.

$\langle\lambda \mathrm{x}[\operatorname{SEE}(\mathrm{x})(\mathrm{M})], \mathrm{J}\rangle$, where $\mathrm{J} \in$ PERSON

c. *[Máry $]_{\mathrm{F}}$ saw John.

$\langle\lambda x[\operatorname{SEE}(J)(x)], M\rangle$, where $M \in$ PERSON

d. *Mary saw [Die Kinder

$\langle\lambda \mathrm{x}[\operatorname{SEE}(\mathrm{x})(\mathrm{M})], \mathrm{KF}\rangle$, where $\mathrm{KF} \notin \mathrm{PERSON}$ der Fínsternis $]_{\mathrm{F}}$.

We conclude that there are ways to represent the contribution of the focus of the answer in both the proposition set framework and the structured meaning framework. But let us turn now to cases that present a problem for the proposition set analysis.

\subsection{Underfocused and Overfocused Answers}

Consider the following question-answer pairs:

(30) A: What did Mary do?

B: Mary [read Die Kinder der Finsternis $]_{\mathrm{F}}$.

B': *Mary read [Die Kinder der Finsternis $]_{\mathrm{F}}$.

B": *Mary [reád $]_{\mathrm{F}}$ Die Kinder der Finsternis. 
Clearly, A - B is congruent, but A - B' and A - B" are not. Intuitively, the expressions that are focused are too small; I will call such answers underfocused. This does not readily appear in the case A - B' due to an ambiguity of focus marking: If a VP consisting of a verb and an argument is focused, this focus is typically expressed by accenting the argument (cf. Schmerling 1976, Gussenhoven 1983, von Stechow \& Uhmann 1986); but when just this argument is in focus, it will also receive accent. The two cases differ, however, when the argument is given, e.g., pronominal, because then the argument does not receive accent when part of a larger focus:

(31) B: Mary [réad that $]_{\mathrm{F}}$.

B': *Mary read [thát $]_{\mathrm{F}}$.

The converse problem to the one just discussed appears in the following example:

(32) A: What did Mary read?

B: Mary read [Die Kinder der Finsternis $]_{\mathrm{F}}$.

B': *Mary [read Die Kinder der Finsternis $]_{\mathrm{F}}$.

In (32B'), the focus of the answer is too large; it is an overfocused answer. As focus marking is ambiguous, this does not result in ungrammaticality; the answer Mary read Die Kinder der Finsternis can be interpreted as (32B) instead. But in case the object is pronominal, we do find that the answer corresponding to $\mathrm{B}$ ' is ungrammatical:

(33) B: Mary read [thát $]_{\mathrm{F}}$.

B': *Mary [réad that $]_{\mathrm{F}}$.

Another instance of overfocusation is illustrated by the following example:

(34) A: What did Mary do with Die Kinder der Finsternis?

B: $\quad$ Mary $[\text { reád }]_{\mathrm{F}}$ Die Kinder der Finsternis.

B': *Mary [read Die Kinder der Finsternis $]_{\mathrm{F}}$.

We would expect that an adequate theory of questions and congruent answers excludes overfocused and underfocused answers. Let us check whether this is the case with the two frameworks that we have discussed. We start with the proposition set framework, in Hamblin's version. Take the following example of an underfocused answer: 
(35) a. What did Mary do?

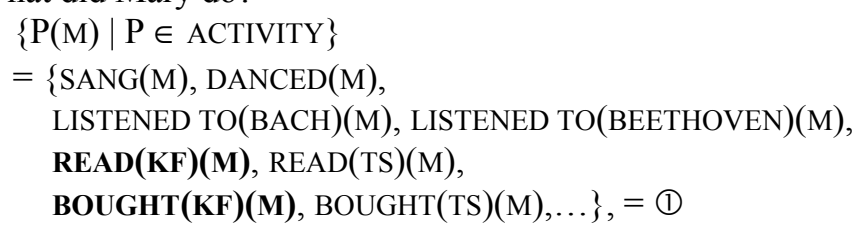

b. *Mary $[\text { reád }]_{\mathrm{F}}$ Die Kinder der Finsternis. Alternatives: $\{\mathrm{R}(\mathrm{KF})(\mathrm{M}) \mid \mathrm{R} \in \mathrm{ALT}(\mathrm{READ})\}$ $=\{\operatorname{READ}(\mathrm{KF})(\mathrm{M}), \operatorname{BOUGHT}(\mathrm{KF})(\mathrm{M}), \ldots\},=$ (2)

The question is whether any one of the three criteria for congruent question-answer pairs listed in (24) rules out this answer. Notice that we have (2) $\subseteq$ (1), and also \#(1) $\cap$ (2) $>1$, hence the criteria (24b) and (c) will not do. We might see this as evidence that we should take the first criterion, (24a), as we don't have (1) $\subseteq$ (2). But now we run into the problem of overfocused answers:

(36) a. What did Mary do with Die Kinder der Finsternis?

$\{\mathrm{R}(\mathrm{KF})(\mathrm{M}) \mid \mathrm{R} \in$ DIRECTED ACTIVITY $\}$

$=\{\operatorname{READ}(\mathrm{KF})(\mathrm{M}), \operatorname{BOUGHT}(\mathrm{KF})(\mathrm{M}), \ldots\},=$ (1)

b. *Mary $[\mathrm{read} \text { Die Kinder der Finsternis }]_{\mathrm{F}}$ $\{\mathrm{P}(\mathrm{M}) \mid \mathrm{P} \in \operatorname{ALT}(\operatorname{READ}(\mathrm{KF}))\}$

$=\{\operatorname{SANG}(\mathrm{M}), \operatorname{DANCED}(\mathrm{M})$, LISTENED TO(BACH)(M), LISTENED TO(BEETHOVEN)(M), READ(KF)(M), READ(TS)(M), BOUGHT(KF)(M), BOUGHT(TS)(M), .. $\}$, = (2)

According to the first criterion, (24a), this should be a congruent answer, which it is not. We run into problems with all three criteria for the proposition set theory. The identification strategy (25) doesn't work either:

(37) a. What did Mary do with Die Kinder der Finsternis?

$\{\mathrm{R}(\mathrm{KF})(\mathrm{M}) \mid \mathrm{R} \in$ directed activity, $\mathrm{R} \in \mathrm{RESTR}\},=$ (1)

b. *Mary $[\mathrm{read} \text { Die Kinder der Finsternis }]_{\mathrm{F}}$ $\{\mathrm{P}(\mathrm{M}) \mid \mathrm{P} \in \operatorname{ALT}(\operatorname{READ}(\mathrm{KF}))\},=$ (2)

Notice that accommodation (1) $=$ (2), with $\#((1))>1$, is possible, leading to (1) $=$ (2) $=$ $\{\operatorname{READ}(\mathrm{KF})(\mathrm{M})$, BOUGHT(KF)(M)\}

Hence (25) does not predict either that this question-answer pair is not congruent.

This is not a problem specific to Hamblin's version of the proposition set theory. It would appear in Karttunen's version as well, which differs from Hamblin's only insofar as the propositions in the question meaning are reduced to the ones that are true. It 
also appears in Groenendijk \& Stokhof's theory. For our example (35), that theory would give us a similar representation, except that we should understand the propositions in the question meaning as holding exhaustively. Presumably, the alternatives created by focus in the answer should be interpreted exhaustively as well. But then the problems of over- and underfocused answers as illustrated in (35) and (36) appear.

The danger of over- and underfocusation in Alternative Semantics has been observed with contrastive focus by Schwarzschild (1994). He draws attention to the fact that $(38 \mathrm{a}, \mathrm{b})$, but not $(\mathrm{c})$, are adequate contrastive statements in the given context:

(38) A: John picked strawberries at Mary's farm.

a. B: No, John picked strawberries at Sándy's $\mathrm{S}_{\mathrm{F}}$ farm.

b. B: No, John picked blúeberries ${ }_{\mathrm{F}}$ at Sándy' $\mathrm{S}_{\mathrm{F}}$ farm.

c. B: \#No, John picked stráwberries ${ }_{\mathrm{F}}$ at Sándy's $\mathrm{S}_{\mathrm{F}}$ farm.

Sentence (c) is overfocussed. But if the rule for contrastive statements (in Alternative Semantics) is just that the target sentence (here, A) should express a proposition that is an element of the alternatives of the contrastive statement, then (c) should be fine. Schwarzschild's solution is to appeal to a general principle that favors minimal focus. This is a consequence of general pragmatic considerations: focus means added complexity (the introduction of alternatives), and therefore should be used only when necessary. Focus on blueberries in (b) is necessary because the contrastive statement differs in this constituent from the target sentence, but focus on strawberries in (c) is not necessary to satisfy the conditions for contrastiveness, and so (a) should be preferred over (c).

We may try to apply Schwarzschild's Razor - "no complexity without necessity!" to congruent question-answer relations. For example, for Who read Die Kinder der Finsternis, the answer Máry $\mathrm{F}_{\mathrm{F}}$ read Die Kinder der Finsternis is preferred over the answer Máry $y_{\mathrm{F}}$ read [Die Kinder der Finsternis $]_{\mathrm{F}}$ because the alternatives of the first answer form a proper subset of the alternatives of the second answer. Similarly, for the question What did Mary read?, the answer Mary read [Die Kinder der Finsternis] $]_{\mathrm{F}}$ is better than the answer Mary [read Die Kinder der Finsternis $]_{\mathrm{F}}$ because the alternatives of the first answer form a proper subset of the alternatives of the second. In general, then, we would predict that focus is assigned only when necessary, and on as small a constituent as possible, in order to satisfy the condition for congruent question-answer pairs.

The problem of this pragmatic account is that it makes wrong predictions for underfocused answers, as in (35). Here the alternatives of the non-congruent answer form a proper subset of the alternatives of the congruent answer, which would give preference to the non-congruent answer. In the contrastive cases that Schwarzschild considered, underfocused statements as in (39B) are excluded because in this case the meaning of the target sentence (A) is not an element of the set of alternatives (B). 
(39) A: John picked strawberries at Mary's farm.

B: *No, John picked [blúeberries] $]_{\mathrm{F}}$ at Sandy's farm. (where Mary $\neq$ Sandy)

Hence, there is a natural limit for the pragmatic rule that prefers minimal focusation in the case of contrastive statements. But there is no such limit if we apply it to answers to questions.

Also, the general rule, "Focus minimally!", which might work fine for cases with multiple focus as in (38), does not work for single foci. It is not quite clear how to apply this principle to single focus, but either interpretation leads to problems. If we interpret it as saying, "Use a focus as large as possible", then we would run into problems with overfocused answers, and if we interpret it as saying, "Use a focus as small as possible", we would have similar problems with underfocused answers.

What about overfocused or underfocused answers in the structured meaning framework? The problem simply does not arise. Consider the following example of an underfocused answer:

(40) a. What did Mary do?

$\langle\lambda \mathrm{P}[\mathrm{P}(\mathrm{M})]$, ACTIVITY $\rangle$

b. *Mary $[\text { reád }]_{\mathrm{F}}$ Die Kinder der Finsternis.

$\langle\lambda \mathrm{R}[\mathrm{R}(\mathrm{KF})(\mathrm{M})], \mathrm{READ}\rangle$

Notice that the backgrounds don't match: $\lambda \mathrm{P}[\mathrm{P}(\mathrm{M})] \neq \lambda \mathrm{R}[\mathrm{R}(\mathrm{KF})(\mathrm{M})]$. Hence, $(40 \mathrm{~b})$ is correctly ruled out. - Consider now the case of an overfocused answer:

(41) a. What did Mary do with Die Kinder der Finsternis?

$\langle\lambda \mathrm{R}[\mathrm{R}(\mathrm{KF})(\mathrm{M})]$, DIRECTED ACTIVITY $\rangle$

b. *Mary [read Die Kinder der Finsternis $]_{\mathrm{F}} . \quad\langle\lambda \mathrm{P}[\mathrm{P}(\mathrm{M})], \operatorname{READ}(\mathrm{KF})\rangle$

Again, the backgrounds don't match; we have $\lambda R[R(K F)(M)] \neq \lambda \mathrm{P}[\mathrm{P}(\mathrm{M})]$. So, the structured meaning framework clearly fares better than the proposition set framework.

\section{Problems with Alternative Questions}

\subsection{Alternative Questions}

We have seen above in (8) and (11) that both the proposition set framework and the structured meaning framework can deal with polarity questions, even though the structured meaning framework has a slight advantage as it could provide us with meanings for the simple answers yes and no. Now, there is a question type that is sometimes confused with polarity questions but that belongs to a quite different type 
known as alternative questions. The following examples illustrate the two question types:

(42) A: Did Mary read Die Kinder der Finsternis?

B: Yes. / No.

(43) A: Did Mary read Die Kinder der Finsternis, or didn't she?

B: $\quad *$ Yes. / No.

B': She read it. / She didn't read it.

In contrast to polarity questions, alternative questions cannot be answered by yes and no, but require a full answer, or at least answers like Yes, she did or No, she didn't. Bolinger (1978b) discusses the differences between the two question types in detail. There is some overlap: both (42A) and (43A) can be answered by Yes, she did and No, she didn't. Also, the marking of polarity questions in some languages betrays alternative questions as their historical source, e.g., in so-called A-not-A questions in Chinese (cf. Li \& Thompson 1981).

(44) ta zai jia bu zai jia?

$3 . s g$ at home not at home

'Is s/he at home?'

But a proper analysis of questions will have to clearly distinguish between polarity questions and alternative questions (in contrast to Karttunen 1977, who considers the first a subclass of the second).

Alternative questions like (43) that may wrongly be analyzed as polarity questions are just one type of alternative question. Other types of alternative questions are clearly distinct:

(45) A: Do you want téa or cóffee?

B: Téa

B': I want téa $\mathrm{F}_{\text {. }}$

(45A) may formally look like a polarity question. But the answers show that they are semantically rather a type of constituent question, where the question domain is given explicitly by the disjunctive phrase. The alternative question (45A) has exactly the same answer condition as the constituent question What do you like, tea or coffee? (cf. Bäuerle 1979). This leads to the following analyses of (45A) in the proposition set framework and the structured meaning framework (cf. von Stechow 1993 for the proposition set analysis): 
(46) a. Do you want téa or cóffee? (expected answers: tea, or coffee).

b. Proposition set analysis: $\quad$ WWANT(TEA)(YOU), WANT(COFFEE)(YOU)\}

c. Structured meaning analysis: $\langle\lambda x[$ WANT(x)(YOU)], \{TEA, COFFEE $\}\rangle$

Notice that in alternative questions the members of the disjunctive phrase are stressed. (46a) contrasts with the polarity question (47a):

(47) a. Do you want tea or coffee? (expected answers: yes, or no):

b. Proposition set analysis:

$$
\begin{aligned}
& \{[\text { WANT(TEA)(YOU) } \vee \text { WANT }(\text { COFFEE })(\text { YOU })], \\
& \neg[\text { WANT }(\text { TEA })(\text { YOU }) \vee \text { WANT }(\text { COFFEE })(\text { YOU })]\}
\end{aligned}
$$

c. Structured meaning analysis:

$$
\langle\lambda \mathrm{f}[\mathrm{f}([\mathrm{WANT}(\mathrm{TEA})(\mathrm{YOU}) \vee \mathrm{WANT}(\mathrm{COFFEE})(\mathrm{YOU})])],\{\lambda \mathrm{p}[\neg \mathrm{p}], \lambda \mathrm{p}[\mathrm{p}]\}\rangle
$$

Stress is an alternative to $w h$-movement for signaling that an expression is to be associated with a question operator, leading to a question meaning. We often find stress as a marking device for question word meanings in wh-in-situ languages, like Korean (cf. Hong 1995):

$$
\begin{aligned}
& \text { (48) a. Mary-ka mwues-ul masi-ess-ni? } \\
& \text { Mary-NOM what-ACC drink-PAST-QUEST } \\
& \text { 'Did Mary drink something/anything?' }
\end{aligned}
$$

b. Mary-ka mwués-ul masi-ess-ni? 'What did Mary drink?'

\subsection{Alternative Polarities}

Consider now the analysis of (43), an alternative question that presents a proposition and its negation as the two options. The only way to render its meaning in the proposition set analysis is as in (49), which is the same meaning as the one proposed for the polarity question (12).

(49) Did Mary read Die Kinder der Finsternis, or didn't she? $\{\operatorname{READ}(\mathrm{KF})(\mathrm{M}), \neg \operatorname{READ}(\mathrm{KF})(\mathrm{M})\}$

But we have seen in our discussion of (42) and (43) that alternative questions, even those that have alternative truth polarities, are different from polarity questions. It seems that the proposition set approach does not offer any representation that would give us a different meaning for polarity questions and alternative questions if the alternative question highlights a sentence and its negation. 
The structured meaning framework, on the other hand, can distinguish between the following representations, which match polarity questions and alternative questions as indicated by their expected answers.

(50) a. Did Mary read Die Kinder der Finsternis? $\langle\lambda \mathrm{f}[\mathrm{f}(\operatorname{READ}(\mathrm{KF})(\mathrm{M}))],\{\lambda \mathrm{p}[\neg \mathrm{p}], \lambda \mathrm{p}[\mathrm{p}]\}\rangle$

b. Did Mary read Die Kinder der Finsternis, or didn't she?

$\langle\lambda \mathrm{p}[\mathrm{p}],\{\operatorname{READ}(\mathrm{KF})(\mathrm{M}), \neg \operatorname{READ}(\mathrm{KF})(\mathrm{M})\}\rangle$

In (50a), the truth-value operators $\lambda \mathrm{p}[\neg \mathrm{p}]$ and $\lambda \mathrm{p}[\mathrm{p}]$ form the restriction, which enables the answers no and yes. In the meaning of the alternative question (b), the propositions themselves form the restriction, which enables answers like Mary read Die Kinder der Finsternis and Mary didn't read Die Kinder der Finsternis.

Once more, the structured meaning framework allows for more distinctions than the proposition set framework, and it appears that these distinctions are necessary.

\section{Problems with Multiple Constituent Questions}

\subsection{Multiple Constituent Questions}

A third area in which the structured meaning framework fares better concerns multiple constituent questions, that is, questions with more than one question constituent. We have to distinguish a number of types of such questions (cf. Wachowicz 1974, Comorovski 1996).

The first type is matching questions. These are questions that presuppose a list answer. Examples are given in (51) to (53):

(51) A: Whó read whát?

B: Máry read Die Kinder der Fínsternis, and Jóhn read Das Tótenschiff.

(52) A: Whó left whén?

B: Máry left at fóur, and Jóhn left at four-thírty.

(53) A: Whó went whére whén?

B: Máry went to Spáin in Septémber, and Jóhn went to Fránce in Júly.

A different type of multiple constituent question is illustrated in the following examples. These questions do not presuppose a list answer, and they are expressed differ- 
ently from matching questions, usually involving a conjunction. They are commonly called conjoined questions.

(54) A: Whó left, and whén?

B: Máry left, at fóur.

(55) A: Whó read something, and whát?

B: Máry read something, namely Die Kinder der Finsternis.

There is a type of question that appears quite similar to matching questions in its syntactic form, but which presupposes that there is only a single answer, and hence is similar to conjoined questions in its semantics:

(56) A: Whát maestro is conducting whát orchestra in the performance of whát symphony at tonight's concert?

B: Bérnstein is conducting the Boston $\mathrm{S}_{\mathrm{Y}}$ ' mphony orchestra in the performance of Beethoven's Fifth Sy' mphony.

(57) A: Whích French general invaded whích Eastern-European empire in whích year?

B: Napóleon invaded Rússia in eighteen twélve.

Example (56) is from Åqvist (1965), who took it to show that multiple questions need not be answered by a list. However, Wachowicz (1974) points out that these questions are typically pronounced with an intonation phrase after every question phrase, which she takes as indicating that these questions are to be interpreted conjunctively, and not as matching questions.

Wachowicz also observes that questions of this type are often used in quizzes, that is, the person that asks the question already knows the answer. Hence she calls them quiz questions. This is indeed a typical use of such questions, but it is probably not a defining criterion; a question like (56) can be uttered as a sincere request for information. But what is typical for these questions is that they are about a particular event (in our examples, tonight's concert and a particular event in history). This makes them good candidates for quizzes, which often ask for information about a particular event.

Another type of multiple constituent question is echo questions, as in the following example:

(58) A: Esmeralda needs a bandoneon.

B: Whó needs whát?

Of course, echo questions need not be multiple constituent questions; Esmeralda needs whát? or Whó needs a bandoneon? are proper echo questions in reaction to (58A) as 
well. The question constituent in echo questions asks for the specification of phonological information of the preceding sentence, either because it was not understood properly, or because the hearer is reluctant to believe what is expressed by the first sentence. In a sense, echo questions are a variety of quiz question because both question types are about a particular event - standard quiz questions about an event that the speaker assumes to be identifiable by the hearer, and echo questions more specifically about a speech event, the utterance of the preceding sentence. Of course, they differ in other respects; echo questions are just about phonological material and hence can disregard many restrictions on $w h$-elements otherwise found.

In the following, I will mainly concentrate on matching questions, but it is critical to first establish them as a type that is separate from conjoined questions, including multiple quiz questions and echo questions. There are indeed a number of differences.

First, for matching questions there is a restriction that the wh-constituents must be clausemates. Kuno \& Robinson (1972), building on work by Baker (1970), observe the following minimal pairs:

(59) a. I don't know who expects who to marry Mary.

b. *I don't know who expects that who will marry Mary.

(60) a. I cannot tell you who I like better than who.

b. *I cannot tell you who I like better than I like who.

The syntactic nature of this constraint is not quite clear, as root questions in which the second question constituent is embedded in a complex noun phrase are fine (cf. Which student bought the book that which professor recommended?). It may be that clausemate cases are preferred over non-clausemate cases with a similar meaning; notice that there is no alternative clausemate construction if the question constituent occurs in a complex noun phrase. In any case, the clausemate constraint does not obtain for echo questions and quiz questions:

(61) Quiz show moderator:

Now, for 500 dollars, whó expects that whó will marry Mary?

(62) A: (almost inaudible): John expects that Bill will marry Mary.

B: What did you say? Whó expects that whó will marry Mary?

Second, question formation is known to lead to ungrammaticality in weak-crossover contexts:

(63) $* \mathrm{Who}_{1}$ does his ${ }_{1}$ mother adore $\mathrm{t}_{1}$ ?

But this does not hold for echo questions (cf. Wachowicz 1974, an observation attributed to Cole 1972): 
(64) A: (almost inaudible): You must know, his mother adóres Jonathan.

B: Whó ${ }_{1}$ does his 1 mother adore?

Weak-crossover effects are absent in quiz questions as well, including multiple quiz questions:

(65) Whích Roman emperor ${ }_{1}$ did whích of his ${ }_{1}$ female relatives despise $t_{1}$ so much that she had him poisoned?

This contrasts with matching questions, where we find weak-crossover effects:

(66) A: Whích Roman emperor ${ }_{1}$ did whích of his ${ }_{1}$ female relatives despise $t_{1}$ ?

B: *Tibérius, his dáughter despised, and Néro, his móther.

A further difference is that matching questions on the one hand and conjoined questions and quiz questions on the other are sometimes expressed differently in some languages (cf. Comorovski 1996:134ff., for Romanian).

(67) a. Cine si $_{1} \quad \mathrm{ce}_{1} \quad\left[\mathrm{t}_{1} \mathrm{ti}-\mathrm{a} \quad\right.$ spus $\left._{2}\right]$ ? who and what to.you-has told

'Who told you what?' (expects single answer)

b. Cine $_{1} \quad$ ce $_{1} \quad\left[\mathrm{t}_{1} \mathrm{ti}-\mathrm{a} \quad\right.$ spus $\left._{2}\right]$ ?

who what to.you-has told

'Who told you what?' (list answer preferred)

For non-arguments we find a similar construction in German:

(68) a. Wann und wo hast du Urlaub gemacht?

when and where have you vacation made

'When did you go on vacation, and where?' (single answer)

b. Wánn hast du wó Urlaub gemacht?

when have you where vacation made

'When did you go on vacation where?' (list answer preferred)

However, in both cases the pattern identified for matching questions, (67b) and (68b), can also be used for quiz questions, though not as the preferred form. 


\subsection{Conditions for Matching Questions}

We have seen that one important condition for matching questions is that they require a list answer. An answer with a single sentence is not felicitous; the question presupposes that there is more than one answer.

(69) A: Whó saw Bob whén?

B: *Máry, at fóur. (o.k. in quiz interpretation, Who saw Bob, and when?)

In case a list answer is excluded for extraneous reasons, matching questions are infelicitous, as pointed out by Wachowicz (1974).

(70) a. *Whó killed John F. Kennedy whén? o.k. only in "quiz" interpretation.

b. Whó killed whích American President whén?

Another condition for matching questions is that one of the question constituents is linked to a contextually given set; cf. Comorovski (1985) and Pesetsky (1987). They are $\mathbf{D}$ (iscourse)-linked. Typically, the D-linked phrase is the first question constituent. This explains the following contrast (cf. Comorovski 1996).

(71) a. Who on earth broke the expensive Chinese vase?

b. *Who on earth broke what?

The phrase on earth indicates that the domain for who should be taken as widely as possible, hence it marks the phrase as not D-linked. This is in conflict with the requirement of matching questions that the first question constituent be D-linked.

It is typically the subject that is D-linked, and non-D-linked expressions cannot be moved in front of D-linked expressions, an effect known as superiority (cf. Chomsky 1973).

(72) a. Whó read whát?

b. " Whát did whó read?

But there are well-known exceptions. Which-phrases, which presumably are always Dlinked, can violate superiority (cf. Karttunen 1977; cf. (73)), and appropriate contexts can also lead to acceptable violations of superiority (cf. Bolinger 1978a, Pesetsky 1987; cf. (74)):

(73) Which girl did which boy kiss? 
(74) I know that we need to install transistor A, transistor B, and transistor C, and I know that these three holes are for transistors, but I'll be damned if I can figure out from the instructions whére whát goes.

Bolinger (1978a) suggests that D-linking induces fronting of a question constituent, and that question constituents that are not D-linked remain in an interior position. However, it seems that the subject is an exception to this rule, as it has to be understood as D-linked even when occurring in a non-fronted position. This was pointed out by Comorovski (1996:85) with the low acceptability of a question like the following:

(75) ?? Which book did how many people buy?

The subject, how many people, cannot normally be interpreted as D-linked, even if it occurs in an interior position. It refers to a number, and numbers are normally not given by the context. But, of course, other $w h$-constituents in an interior position need not be D-linked. It seems that a matching question in which one $w h$-constituent is Dlinked is "about" the antecedent set of this constituent. Consequently, Bolinger (1978a) identifies the first $w h$-phrase of a matching question as the topic of this question.

Kuno (1982) suggests another way of describing the unequal role of the question constituents in a matching question. According to him, the fronted constituent represents the sorting key to access the relevant pieces of information in the answer.

(76) A: Which of these climatic conditions occur in which countries?

B: Typhóons occur in Japan, Korea, and China; húrricanes occur in the Carribean and in the southern US; ...

(77) A: In which countries do which of these climatic conditions occur?

B: In Japán, typhoons and early-summer rain spells occur; in Tháiland, they have monsoons; ...

Notice that answer (76B) would be odd for question (77A), and answer (77B) would be infelicitous for question (76A). This is because in (76A) the sorting key is the set of climatic conditions, whereas in $(77 \mathrm{~A})$ the sorting key is the set of countries, and the answer of a matching question should be from the perspective of the sorting key of the question. Kuno's account can be related to D-linking by the plausible assumption that sorting keys must be given, i.e., D-linked.

Another condition worth mentioning is that matching questions usually presuppose that every element in the set denoted by the D-linked question constituent is part of one answer in the answer list. That is, matching questions are interpreted distributively. This explains the following contrast: 
(78) We had a list of criminals, and we knew for sure that at least some of them were involved in the crimes. The question we had to solve, then, was:

a. Which crime was committed by which criminal.

b. Which crime did which criminal commit.

c. ?"Which criminal committed what crime.

In the context given, the questions are about the crimes, not about the criminals; hence, the crimes are D-linked and the sorting key. This explains why (a), a form in which the phrase which crime occurs in subject position, is preferred over (c), and why even superiority violations as in (b) are allowed.

Finally, there is a curious contrast that shows up with embedded questions (cf. Karttunen 1977):

(79) a. Mary knows which student read which book.

b. *Mary knows whether John read which book.

Whether marks embedded polarity questions (or alternative questions, cf. whether John wants téa or cóffee; we have noticed this formal similarity already for root questions above). We can analyze whether as a question constituent that ranges over the truth value of sentences, but then it remains to be explained why it is different from other question constituents in not allowing for matching questions. In light of the discussion above, the reason why (79b) is out is the following: whether is the first question constituent, which is typically interpreted as D-linked, but truth values are never D-linked.

\subsection{The Semantics for Matching Questions}

What do the observations of the previous section tell us about the semantics of matching questions? They clearly make it impossible to defend an analysis for which the question constituents are treated on a par. It is useful to compare matching questions in natural languages with the semantics of queries in a database language like Prolog (cf. Clocksin \& Mellish 1981), which can be given as follows:

(80) A question with multiple wh-elements $\left[\mathrm{wh}_{1} \ldots \mathrm{wh}_{2} \ldots \mathrm{wh}_{3} \ldots\right]$ asks for which tuples $\left\langle\mathrm{X}_{1}, \mathrm{X}_{2}, \mathrm{X}_{3}\right\rangle$ the sentence $\left[\mathrm{X}_{1} \ldots \mathrm{X}_{2} \ldots \mathrm{X}_{3} \ldots\right]$ is true.

It is easy enough to implement this in both the proposition set analysis and the structured meaning framework: 
(81) Who read what?
a. Proposition set analysis:
$\{\operatorname{READ}(\mathrm{y})(\mathrm{x}) \mid \mathrm{x} \in$ PERSON, $\mathrm{y} \in \mathrm{THING}\}$
$=\{\operatorname{READ}(\mathrm{KF})(\mathrm{M}), \operatorname{READ}(\mathrm{TS})(\mathrm{M}), \ldots$
$\operatorname{READ}(\mathrm{KF})(\mathrm{J}), \operatorname{READ}(\mathrm{TS})(\mathrm{J}), \ldots\}$
b. Structured meaning analysis: $\quad\langle\lambda\langle\mathrm{x}, \mathrm{y}\rangle[\operatorname{READ}(\mathrm{y})(\mathrm{x})]$, PERSON $\times$ THING $\rangle$

In the proposition set analysis, both question constituents introduce alternatives, resulting in the set of propositions (81a). One simple way of implementing matching questions in the structured meaning approach is to assume that the background is a function over pairs (or triples, quadruples...), with the domain defined as the Cartesian product of the domains of the question constituents.

But this does not explain the condition we found for matching questions. In particular, it does not rule out answers that consist of single pairs (cf. (69)) or answers in which the first question constituent is not D-linked (cf. (71)), and it does not capture the fact that one question constituent acts as a sorting key (cf. (76)).

There are certainly ways to implement these additional restrictions, and we will turn to this issue below. But the question that arises here is: Why do natural languages not have questions of the type of Prolog queries as in (80)?

I suggest that a database query like (80) is cognitively too complex to be carried out in one go, as it asks for two things simultaneously, and we can answer only one thing at a time. The query asks us to inspect the whole database, taking note of any pairs or triples that satisfy the condition expressed by the question. If $\mathrm{n}$ is the number of entities in the database, and $x_{i}$ is the $i$-th entity, then what (81) requires us to do is the following:

(82) For $\mathrm{i}:=1$ to $\mathrm{n}$ do:

$$
\begin{aligned}
& \text { Is } \mathrm{x}_{\mathrm{i}} \text { a person? } \\
& \text { If yes: For } \mathrm{j}:=1 \text { to } \mathrm{n} \text { do: } \\
& \text { Is } \mathrm{x}_{\mathrm{j}} \text { a book? } \\
& \text { If yes: Did } \mathrm{x}_{\mathrm{i}} \text { read } \mathrm{x}_{\mathrm{j}} \text { ? } \\
& \text { If yes: Print } \mathrm{x}_{\mathrm{i}}, \mathrm{x}_{\mathrm{j}} \text { ! }
\end{aligned}
$$

Such searches in two or more dimensions appear to be too demanding, at least when applied to the whole knowledge base.

What seem to be licit cases of asking for more than two things at a time actually turn out to be cases of asking only one thing at a time. This is obvious for conjoined questions, which unfold into two or more questions:

(83) a. Conjoined question: Who came, and when?

b. Question 1: Who came? Answer: Mary. Question 2: When did Mary come? Answer: At noon.

c. Conjoined answer: Máry, at nóon. 
Answering this question involves the following steps:

(84) a. For $\mathrm{i}:=1$ to $\mathrm{n}$ do:

Is $\mathrm{x}_{\mathrm{i}}$ a person that came?

If yes: Print $\mathrm{x}_{\mathrm{i}}$ and stop loop.

b. For $\mathrm{j}:=1$ to $\mathrm{n}$ do:

Is $\mathrm{x}_{\mathrm{j}}$ a time at which $\mathrm{x}_{\mathrm{i}}$ came?

If yes: Print $\mathrm{x}_{\mathrm{j}}$ and stop loop.

What about quiz questions like (56) and (57)? They are about a particular event that is left unspecified with respect to one or more participants or parameters, and they are understood by the hearer as being about a particular event. This means that they can be answered without going through the whole database; rather, the hearer is asked to focus on a single, unique event, and specify the parameters left open in the question. Question (56) is answered as follows:

(85) Identify in your database the unique event in which a French general invaded an Eastern-European empire.

Print the name of the general, the empire, and the year of the event.

Similarly, echo questions are about a particular event - a preceding utterance that was incompletely understood.

What, then, about matching questions? I would like to argue that they, too, are answered by only one "thing", but that this thing is a function. Of course, if we see a function extensionally as a set of tuples, asking for more than one thing at a time and asking for a function would be the same. But I would like to restrict the cognitively relevant sense of "function" to mapping procedures from a given and identifiable domain to values, and claim that such procedures, though complex, can be considered one "thing" that we can ask for. To illustrate, answering the matching question (51A) involves the following steps:

(86) For $\mathrm{i}:=1$ to $\mathrm{n}$ do:

Is $f_{i}$ a function from the persons mentioned to (readable) things?

If yes: Does it hold for every $x$ in the domain of $f_{i}$ that $x$ read $f_{i}(x)$ ? If yes: Print $f_{i}$ and stop.

Several observations about matching questions that we made earlier follow from this account. If cognitive functions require a given domain (a mapping procedure must apply to some set), then the question element that defines the domain must be Dlinked. The elements in the domain naturally are the "sorting key", as cognitive functions are nothing but a way of identifying certain entities by way of other entities. If cognitive functions are mapping procedures for a domain, then it follows that they should map each element of the domain to something, hence, have a distributive inter- 
pretation. And the domain should contain more than one element; a domain with one or zero elements would result in a degenerate function that is not "really" a function, just as a line or a point, which qualify as triangles in the mathematical sense, are not "really" triangles.

If matching questions ask for a mapping procedure, then the question constituents should be used to construct this procedure. This is possible with the structured meaning account, as domain and range of the function are accessible. Currently, our theory would give us the following interpretation for Prolog queries:

(87) Who read what? $\langle\lambda\langle\mathrm{x}, \mathrm{y}\rangle[\operatorname{READ}(\mathrm{y})(\mathrm{x})]$, PERSON $\times \mathrm{THING}\rangle$

This is a question that asks for more than one thing at a time and cannot be answered. But it can be transformed into a question that asks for a mapping procedure by using the following operators:

(88) a. $\mathrm{FUN}(\mathrm{R})=\lambda \mathrm{f} \forall \mathrm{x}[\mathrm{x} \in \mathrm{DOM}(\mathrm{f}) \rightarrow \mathrm{R}(\langle\mathrm{x}, \mathrm{f}(\mathrm{x})\rangle)]$, the set of functions $f$ such that every $x$ in the domain of $f$ stands in R-relation to $\mathrm{f}(\mathrm{x})$

b. $F U N^{\prime}(A \times B)=$ the set of functions from $A$ to $B$

Applied to our example, we get the following result:

(89) $\left\langle\mathrm{FUN}(\lambda\langle\mathrm{x}, \mathrm{y}\rangle[\operatorname{READ}(\mathrm{y})(\mathrm{x})]), \mathrm{FUN}^{\prime}(\right.$ PERSON $\left.\times \mathrm{THING})\right\rangle$, where $\operatorname{FUN}(\lambda\langle\mathrm{x}, \mathrm{y}\rangle[\operatorname{READ}(\mathrm{y})(\mathrm{x})])=\lambda \mathrm{f} \forall \mathrm{x}[\mathrm{x} \in \operatorname{DOM}(\mathrm{f}) \rightarrow \operatorname{READ}(\mathrm{f}(\mathrm{x}))(\mathrm{x})]$, the set of functions $f$ such that every $x$ in the domain of $f$ read $f(x)$, and $\mathrm{FUN}^{\prime}(\mathrm{PERSON} \times \mathrm{THING})=$ the set of functions from PERSON to THING.

The answer then specifies a function by enumeration:

(90) Mary Die Kinder der Finsternis, and John Das Totenschiff.

$\mathrm{f}:\{\mathrm{M}, \mathrm{J}\} \rightarrow\{\mathrm{KF}, \mathrm{TS}\}$

$\mathrm{M} \rightarrow \mathrm{KF}$

$\mathrm{J} \rightarrow \mathrm{TS}$

A similar combination of the question constituents to form matching questions has been suggested by Higginbotham \& May (1981) for wh-expressions on the level of logical form (called absorption).

What is important for our current purposes is that the construction of functions as in (88) requires a structured meaning framework; it cannot be expressed in the proposition set framework. It needs access to the question constituents and the background of the sentence in order to construct the function that defines the question, and this is provided by structured meanings but cannot be retrieved from proposition sets. 


\section{Embedded Questions}

We have seen three arguments that favor the structured meaning account of questions over the proposition set account, arguments related to the focusation of answers, alternative and polarity questions, and matching questions. The question now is, is there any problem with the structured meaning analysis that the proposition set analysis could handle better?

As far as I can see, the main argument against a structured meaning analysis of questions is that it may not be able to account for embedded questions (cf. Karttunen 1977). The reason is that question-embedding verbs allow for different types of questions:

(91) a. John knows what Mary read.

b. John knows whether Mary read Die Kinder der Finsternis.

c. John knows who read what. type of background: $\langle\mathrm{e}, \mathrm{t}\rangle$

type of background: $\langle\langle t, t\rangle, t\rangle$

type of background: $\langle e,\langle e, t\rangle\rangle$

Also, questions of different types can be conjoined:

(92) John knows [what Mary read and whether she liked it].

For the proposition set analysis this is not a problem, as all questions are of the same type, namely, sets of propositions. As many question-embedding verbs also embed that-clauses (cf. (93)) and questions and that-clauses can be conjoined (cf. (95)), Hamblin suggests interpreting declarative sentences by sets of propositions as well, namely, as singleton sets. In Groenendijk \& Stokhof's theory, all questions have the same type, and extensions of questions have the same type as that-clauses.

(93) John knows that Mary read Die Kinder der Finsternis.

(94) John knows what Mary read and that she liked it.

This suggests that we should look for a more general analysis for the type variation of question-embedding verbs and coordination, which hopefully then will also be able to cope with the variation that we find for different types of questions.

This is indeed possible. For question-embedding verbs of the type of know, we can assume a lexical rule that connects the two uses we are interested in here:

(95) John knows $Q \Leftrightarrow$

For every answer meaning $A$ that answers the question $Q$, if $\mathrm{A}$ is true, then John knows that $A$, and if $A$ is not true, then John knows that not $A$. 
This lexical rule, illustrated here with reference to expressions instead of meanings, reduces knowing wh-to knowing that in an obvious and general way. It expresses the "exhaustive" interpretation of know, which may be too strong; in order to say that John knows $Q$, it may be sufficient that John knows some answers of $Q$ (cf. Ginzburg 1995). The universal quantifier over answer meanings may just be the default option; see Berman (1989) and Lahiri (1991) for cases with overt quantifiers.

What is important for us is that the schema illustrated in (95) applies for questions of every type. This predicts that know, as a question-embedding expression, is polymorphous in its type requirements.

(96) a. John knows whether Mary read Die Kinder der Finsternis.

$\Leftrightarrow \quad$ For every answer $A$ that answers the question Did Mary read Die

Kinder der Finsternis?

if $A$ is true, then John knows that $A$, and

if $A$ is false, then John knows that not $A$.

i.e., if Mary read Die Kinder der Finsternis, John knows that, and if Mary didn't, John knows that.

b. John knows who read what.

$\Leftrightarrow \quad$ For every answer $A$ that answers the question Who read what?

if $A$ is true, then John knows that $A$, if $A$ is false, then John knows that not $A$.

For so-called "intensional" question-embedding verbs like wonder we will have to assume rules of the following type; they cannot be reduced to corresponding thatclauses.

(97) John wonders $Q \Leftrightarrow$ John wants to know the true answers $A$ to $Q$.

Let us now turn to coordination of questions. Observe that (92) and (94) can be reduced to VP conjunction:

(98) a. John knows what Mary read and whether she liked it.

$\Leftrightarrow \quad$ John knows what Mary read and knows whether she liked it.

b. John knows what Mary read and that she liked it.

$\Leftrightarrow \quad$ John knows what Mary read and knows that she liked it.

This allows for a definition of conjunction and disjunction across different types of questions, and even across questions and that-clauses, using the techniques of typelifting of Boolean structures developed in Keenan \& Faltz (1985). Cross-categorial versions of conjunction, disjunction, and negation can be defined as follows: 
(99) Let M, M' be two meanings (e.g., of questions, or statements). Then we have:

a. $\left[M \wedge M^{\prime}\right]=\lambda f\left[f(M) \wedge f\left(M^{\prime}\right)\right]$

b. $\left[M \vee M^{\prime}\right]=\lambda f\left[f(M) \vee f\left(M^{\prime}\right)\right]$

c. $\neg \mathrm{M} \quad=\lambda \mathrm{f}[\neg \mathrm{f}(\mathrm{M})]$

Here, f ranges over functions whose domains include $M$ and $\mathrm{M}^{\prime}$. The Boolean operators $\wedge, \vee$ and $\neg$ must be defined for the type of $f(M)$ and $f\left(M^{\prime}\right)$. We then have derivations like the following, which shows that know can embed questions of arbitrary type.

(100) [know [[what Mary read] and [whether she liked it $]]]$

$=[[[$ what Mary read $]$ and $[$ whether she liked it $]]]([\mathrm{know}])$

$=\lambda \mathrm{f}[\mathrm{f}([$ what Mary read $]) \wedge \mathrm{f}([$ whether she liked it $])]([$ know $])$

$=[$ know $]([$ what Mary read $]) \wedge[$ know $]([$ whether she liked it $])$

$=$ knows the true answers to what did Mary read, and knows the true answers to did she like it.

We can also treat cases of coordination of a question with a that-clause:

(101) [know [[what Mary read] and [that she liked it $]]]$

$=[\mathrm{know}]([$ what Mary read $]) \wedge[\mathrm{know}]([$ that she liked it $])$

$=\quad$ knows the true answers to what did Mary read, and knows that Mary liked it (= whatever she read).

The question-embedding operator distributes over the members of the conjunction, and the particular interpretation of know (whether know is interpreted as embedding a question or a that-clause) is determined after that distribution.

This is quite similar to cases of coordination of expressions in coercion contexts (cf. Pustejovsky 1993). Take enjoy; this verb subcategorizes for activities (e.g., enjoy swimming in the river) or for NPs (e.g., enjoy a good meal). The latter reading can be reduced to the former; to enjoy $N P$ means to enjoy the prototypical activity related to the referent of $N P$, which might be different for different NPs. Nevertheless, we can conjoin NPs, and even NPs and expressions referring to activities. Such cases can be handled if the specific meaning of enjoy is determined after distribution over the members of the coordination:

(102) a. Mary enjoys a good novel. (= Mary enjoys reading a good novel)

b. Mary enjoys a good meal. (= Mary enjoys eating a good meal)

c. Mary enjoys [[a good novel] and [a good meal]].

$\Leftrightarrow \quad$ Mary [[enjoys a good novel] and [enjoys a good meal]].

$\Leftrightarrow \quad$ Mary [[enjoys reading a good novel] and [eating a good meal]]. 
(103) Mary enjoys [[a good novel] and [swimming in a river]].

$\Leftrightarrow \quad$ Mary [[enjoys a good novel] and [enjoys swimming in a river]].

$\Leftrightarrow \quad$ Mary [[enjoys reading a good novel] and [enjoys swimming in a river]].

We conclude that the type variation of questions under the structured meaning analysis is benign, and cannot be used to argue against this analysis. As a matter of fact, the techniques developed here to cope with the type variation appear to be necessary for independent reasons, in particular for coordination of questions and that-clauses, and for cases of distributed meaning coercions.

\section{Conclusion}

In this article I have discussed two frameworks for the semantics of questions, the structured meaning framework and the proposition set framework. We have seen that the proposition set framework runs into a number of problems:

- It cannot exclude overfocused or underfocused answers.

- It cannot distinguish polarity questions from corresponding alternative questions.

- It does not allow formulation of the proper theory of multiple constituent questions of the "matching question" variety.

The structured meaning account, on the other hand, provides straightforward solutions to these problems. I have also argued that a problem that is often cited for the structured meaning framework, the type polymorphism of embedded questions, can be solved in a non-ad-hoc way.

In general, structured meanings provide more information than the proposition set theory, without going all the way to a fully representational account. It appears that this excess information is necessary for a proper account of questions and their answers.

\section{Acknowledgments}

It is no exaggeration to say that without the inspiring work of Arnim von Stechow, this paper could not have been written. So, it was a happy coincidence that I could present it at the Conference Sinn und Bedeutung in Leipzig, December 13, 1998, in a session that Arnim chaired. I also presented it at the Workshop on Spoken and Written Texts, Austin, January 30, 1999, organized by Carlota Smith. I thank the audiences at both events, in particular Jeroen Groenendijk, Hans Kamp, Paul Portner, Mats Rooth, Peter Staudacher, and, of course, Arnim von Stechow for stimulating discussion. 


\section{References}

Ajdukiewicz, Kazimierz (1928). Logizne Podstawy Nauczania (The Logical Foundation of Teaching).

Aqvist, Lennart (1965). A New Approach to the Logical Theory of Interrogatives. Ms, Uppsala.

Baker, Carl Lee (1970). Notes on the Description of English Questions: The Role of an Abstract Question Morpheme. Foundations of Language 6. 197-219.

Bäuerle, Rainer (1979). Questions and Answers. In: Rainer Bäuerle, Urs Egli \& Arnim von Stechow (eds.) Semantics from Different Points of View. Berlin/Heidelberg/New York: Springer. 61-74.

Berman, Stephen (1989). An Analysis of Quantificational Variability in Indirect Questions. In: Emmon Bach, Angelika Kratzer \& Barbara Partee (eds.) Papers on Quantification. Department of Linguistics, University of Massachusetts at Amherst.

Bolinger, Dwight (1978a). Asking More Than One Thing at a Time. In: Henry Hiz (ed.) Questions. Dordrecht: Reidel. 107-150.

Bolinger, Dwight (1978b). Yes/No Questions Are Not Alternative Questions. In: Henry Hiz (ed.) Questions. Dordrecht: Reidel. 87-105.

Chomsky, Noam (1973). Conditions on Transformations. In: Stephen Anderson \& Paul Kiparsky (eds.) A Festschrift for Morris Halle. New York: Holt, Rinehart \& Winston. 232-286.

Clocksin, William \& Christopher Mellish (1981). Programming in Prolog. Berlin: Springer.

Cole, Peter (1972). Semantic and Syntactic Facts about Wh-Nominals. Paper presented at the LSA Annual Meeting 1972.

Comorovski, Ileana (1985). Discourse-Linked Wh-Phrases. Paper read at the Annual Meeting of the LSA, Seattle, Washington.

Comorovski, Ileana (1996). Interrogative Phrases and the Syntax-Semantics Interface. Dordrecht: Kluwer.

Ginzburg, Jonathan (1992). Questions, Queries and Facts: A Semantics and Pragmatics for Interrogatives. $\mathrm{PhD}$ dissertation, Stanford University.

Ginzburg, Jonathan (1995). Interrogatives: Questions, Facts and Dialogue. In: Shalom Lappin (ed.) The Handbook of Contemporary Semantic Theory. Oxford: Blackwell. $385-422$

Groenendijk, Jeroen \& Martin Stokhof (1984). Studies on the Semantics of Questions and the Pragmatics of Answers. PhD dissertation, University of Amsterdam.

Groenendijk, Jeroen \& Martin Stokhof (1997). Questions. In: Johan van Bentham \& Alice ter Meulen (eds.) Handbook of Logic and Language. Amsterdam: Elsevier. $1055-1124$.

Gussenhoven, Carlos (1983). Testing the Reality of Focus Domains. Language and Speech 26. 61-80.

Hamblin, C. L. (1958). Questions. The Australasian Journal of Philosophy 36. 159-168.

Hamblin, C. L. (1973). Questions in Montague Grammar. Foundations of Language 10. $41-53$. 
Hausser, Roland \& Dietmar Zaefferer (1979). Questions and Answers in a ContextDependent Montague Grammar. In: Franz Guenthner \& S. J. Schmidt (eds.) Formal Semantics and Pragmatics for Natural Languages. Dordrecht: Reidel. 339-358.

Higginbotham, James \& Robert May (1981). Questions, Quantifiers, and Crossing. The Linguistic Review 1. 41-80.

Hiz, Henry (1978). Introduction. In: Henry Hiz (ed.) Questions. Dordrecht: Reidel. IX-XVII.

Hong, Minpyo (1995). Semantics and Pragmatics of Questions and Alternatives. PhD dissertation, University of Texas at Austin.

Hull, R. (1975). A Semantics for Superficial and Embedded Questions in Natural Language. In: Ed Keenan (ed.) Formal Semantics of Natural Language. Cambridge: Cambridge University Press. 35-45.

Jacobs, Joachim (1984). Funktionale Satzperspektive und Illokutionssemantik. Linguistische Berichte 91. 25-58.

Karttunen, Lauri (1977). Syntax and Semantics of Questions. Linguistics and Philosophy 1. $3-44$.

Keenan, Edward \& Leonard M. Faltz (1985). Boolean Semantics for Natural Language. Dordrecht: Reidel.

Krifka, Manfred (1992). A Compositional Semantics for Multiple Focus Constructions. In: Joachim Jacobs (ed.) Informationsstruktur und Grammatik. Opladen: Westdeutscher Verlag. 17-53. [Also in Proceedings of SALT I, 1991. 17-53.]

Kuno, Susumo (1982). The Focus of the Question and the Focus of the Answer. CLS 18: Papers from the Parasession on Nondeclaratives. 134-157.

Kuno, Susumo \& Jane J. Robinson (1972). Multiple Wh Questions. Linguistic Inquiry 3. $463-488$.

Lahiri, Utpal (1991). Embedded Interrogatives and Predicates That Embed Them. PhD dissertation, MIT.

Lewis, David (1970). General Semantics. Synthese 22. 18-67.

Li, Charles \& Sandra Thompson (1981). Mandarin Chinese: A Functional Reference Grammar. Berkeley: University of California Press.

Paul, Hermann (1880). Prinzipien der Sprachgeschichte. [8th edition (1970), Tübingen: Niemeyer.]

Pesetsky, David (1987). WH-in-Situ: Movement and Unselective Binding. In: Erik Reuland \& Alice ter Meulen (eds.) The Representation of (In)Definiteness. Cambridge, MA: MIT Press. 98-129.

Pustejovsky, James (1993). Type Coercion and Lexical Selection. In: James Pustejovsky (ed.) Semantics and the Lexicon. Dordrecht: Kluwer. 73-96

Rooth, Mats (1985). Association with Focus. PhD dissertation, University of Massachusetts at Amherst.

Rooth, Mats (1992). A Theory of Focus Interpretation. Natural Language Semantics 1. 75-116.

Schmerling, Sue (1976). Aspects of English Sentence Stress. Austin: University of Texas Press.

Schwarzschild, Roger (1994). Association with Focus: Semantics or Pragmatics. Ms, Rutgers University. 
Stechow, Arnim von (1981). Topic, Focus, and Local Relevance. In: Wofgang Klein \& Wim Levelt (eds.) Crossing the Boundaries in Linguistics. Dordrecht: Reidel. 95-130.

Stechow, Arnim von (1990). Focusing and Backgrounding Operators. In: Werner Abraham (ed.) Discourse Particles. Amsterdam: John Benjamins. 37-84.

Stechow, Arnim von (1993). Die Aufgaben der Syntax. In: Joachim Jacobs, Arnim von Stechow, Wolfgang Sternefeld \& Theo Vennemann (eds.) Syntax: An International Handbook of Contemporary Research. Berlin: de Gruyter.

Stechow, Arnim von \& Susanne Uhmann (1986). Some Remarks on Focus Projection. In: Werner Abraham \& Sjaak de Meij (eds.) Topic, Focus and Configurationality. Amsterdam: John Benjamins. 295-320.

Stechow, Arnim von \& Thomas Ede Zimmermann (1984). Term Answers and Contextual Change. Linguistics 22. 3-40.

Tichy, Pavel (1978). Questions, Answers, and Logic. American Philosophical Quarterly 15. 275-284.

Wachowicz, Kristina (1974). On the Syntax and Semantics of Multiple Questions. PhD dissertation, University of Texas at Austin. 